Article

\title{
Teresa Żarnower's Mnemonic Desire for Defense of Warsaw: De-Montaging Photography
}

\author{
Maria Anna Rogucka \\ Department of Art and Visual History, Humboldt University, 10117 Berlin, Germany; marogucka@gmail.com
}

Received: 22 April 2020; Accepted: 20 July 2020; Published: 28 July 2020

check for updates

\begin{abstract}
Teresa Żarnower (1897, Warsaw, Poland-1949, New York, United States), a Polish Constructivist artist of Jewish descent who was forced to emigrate abroad during World War II, became a dominant figure working for the Polish government in exile. She produced a series of photomontages for a book titled The Defense of Warsaw, which was published in 1942 by a "Polish Labor Group" in New York. Żarnower used her technical expertise in photomontage to create new configurations of war photographs documenting Nazi Germany's attack on Poland in 1939. She chose this shocking and politically loaded content to gain credibility and global attention for her work. Drawing on Benjamin Buchloh's essay From Faktura to Factography, the aim of this study is to analyze the factographic paradigm in the usage of war photography and in the context of the esthetics of constructivist photomontage. The focus will lie on its mnemonic and archival functions, further highlighting the montage's function as a key form of social memory model.
\end{abstract}

Keywords: Polish constructivist photomontage; politics of architectural photomontage; antiwar book; Jewish female artist; exiled interwar avant-garde; model of social memory; war photography; mnemonic construction of war; iconography of death; documentary methods in art

\section{Introduction}

The first and only monograph on Polish artist Teresa Żarnower was published in 2014 under the title Teresa Żarnowerówna. ${ }^{1}$ Artystka Końca Utopii (1897-1949) [Teresa Żarnower (1897-1949). An Artist of the End of Utopia], by Muzeum Sztuki in Łódź, Poland. ${ }^{2}$ Muzeum Sztuki has a strong avant-garde history as one of the first European institutions to establish a collection of modern art, led by avant-garde artist Władysław Strzemiński (1893, Minsk, Belarus-1952, Łódź, Poland).

Along with his wife Katarzyna Kobro (1898, Moscow, Russia-1951, Łódź, Poland), Strzemiński's work has been internationally researched and widely documented (for instance by Yve-Alain Bois in Painting as model, 1990) (Bois 1990)-in stark contrast to Żarnower, whose art has been little investigated. The clear lack of resources and material gathered on her work, in conjunction with the geographic propagation of the available work across several European countries and in the United

1 The authors of the publication: scholars Milada Ślizińska and Andrzej Turowski give an explanation, to be found on the very first pages, outlining the reasons for keeping the artist's maiden surname in the title with the ending-ówna. First of the introduced reasons is that the artist was not married and that such form of a miss was popular in the environment of the Polish intelligentsia in the inter-war period. In addition, in the artistic circles it was a form of an emancipation, as well as with regard to women with Jewish background, it underlined the declaration of affiliation with Polish culture. As in this paper I am taking the period of "An End of Utopia", I will consciously stick to the 'Zarnower' version of artist's surname, as since her definite departure from Poland to Paris in 1937-and later to the United States-the artist presented herself as Zarnower or Zarnover, as it can be tracked throughout her numerous résumés written in the war period.

2 The museum was founded in 1930, concurrent to other early modernist institutional projects such as El Lissitzky's Cabinet of Abstraction commissioned in 1927 for the Hannover Provincial Museum in Hanover Germany and the founding of the Museum of Modern Art in 1929 in New York, United States. 
States contributed to the inability to complete an "attempted reconstruction of the constructivist trend in Poland", which was suggested back in the early 1980s by Polish art historian Andrzej Turowski (Turowski 1981, p. 238). On the final page of Polska Sztuka Walczaca 1939-1945 [Polish Fighting Art 1939-1945], written by Polish scholar Janina Jaworska in 1976, the list of active Polish artists throughout that period in the United States does not feature Żarnower's name at all (Jaworowska 1976).

In Turowski's seminal publication Budowniczowie świata. Z dziejów radykalnego modernizmu w sztuce polskiej [The Constructors of the World. From the History of Radical Modernism in Polish Art], the author cited Żarnower's Cycle of five photomontages-which is named after and included in The Defense of Warsaw —as one of the artist's most important works (Turowski 2000, p. 216). The Defense of Warsaw was published in New York in 1942 by the active Polish Labor Group, on the initiative of the Polish Socialist Party (Polska Partia Socjalistyczna-PPS), which was operating in exile in France and London. The limited press run of the book prevented a thorough analysis of these photomontages until the 2014 publication of the monograph mentioned above and its two chapters 'Response to a Catastrophe: Cultural Memory in Teresa Żarnower's Photomontages The Defense of Warsaw' and 'Fighting for the Same Cause' by scholar Aleksandra Idzior.

While those chapters use historical research to explain these particular photomontages, in this paper I wish to further the discussion on trans-regional artistic memory practices through the mnemonic and archival functions of both photography and photomontage. In Żarnower's call for Warsaw's defense, the two media touched upon their own narratives of empirical documents. These works were produced and reproduced in a radically shifting cultural and political environment against the backdrop of the exiled artist's loss of familiar social contexts. With this historical context in mind, in this paper I will explore forms of collective didactics, "the modes of simultaneous collective reception" — the indexical signs in the construction of photomontage and the impact of their documentary nature and aspect on the viewer-as investigated by Benjamin Buchloh in his essay From Faktura to Factography in 1984.

The interwar period in Poland from 1918 to 1939 proves problematic in terms of periodization. It is characterized by a rupture in continuity with "a strong anchor in the past and inner displacement of at least three generations — concurrent youth, maturity and an old age. None of the groups (... ) was given a complete clearance of its yes and no towards tradition and presence; none did manage to formulate the vision of the future under the conditions of an independent country" (Grabska 1982, p. 29). The object of this paper's immediate interest is the period from 1939 to 1942. Although, the first point of reference in my analysis goes back to the 1920s, when the first strands of constructivism appeared in Poland-a period of time where Żarnower played a central role. During the 1920s and 1930s_affected by the outcome of the October Revolution in 1917-Żarnower worked towards the fusion of the formal and utilitarian possibilities of new art, based on the development of technology and oriented towards a proletarian audience. Her first political photomontages featured cut-outs from propaganda leaflets addressing the social issues of the peasantry and working classes in interwar Poland. The outbreak of the Second World War led to her engagement with national and international politics. She was first exiled to Paris from 1937 until 1939, where she cooperated with the Polish government's Committee of the Council of Ministers for Information, Documentation and Propaganda, an exiled organization running from Paris and Angers. Through these means, she was able to gain access to archival documents including war photography, which were later used as material for her photomontages in The Defense of Warsaw booklet, originally created in Paris. The booklet could not be published due to France's fall under German occupation in the spring of 1940. In 1940, she fled Paris, reaching Portugal through Spain. On 16 December 1941, Żarnower arrived in America aboard the SS Excalibur, which was commandeered to transport refugees fleeing Europe thanks to the Emergency Rescue Committee. After five days of interrogation, Żarnower was refused entry to the United States and left for Montreal. On 11 June 1943, Zarnower was finally able to relocate to New York with a permanent visa and financial aid organized by the Jewish Labor Committee (Ślizińska and Turowski 2014, pp. 188-200).

Teresa Żarnower, a female Polish-Jewish artist oriented towards leftist politics, worked in exile at both macro and micro levels — both historically and personally-by mediating the events of Germany's 
invasion of Poland. Through Żarnower's war iconography of architectural breaks and ruptures in the form of activist photomontages, the artist commemorated the atrocities that took place in her home country. Using the avant-garde technique of photomontage, Żarnower produced an immediate, artistic response to the Polish socialist activist and publisher Zygmunt Zaremba's September 1939 publication on 27 September 1939. The main focus of the response was the search of a universal language embracing the factographic approach through the continuation of a constructivist interwar montage practice, in the context of the general idea of productivist art. Due to the nature in which this history was written and the kind of material that was available at that time, Żarnower was motivated to collect and montage largely unpublished documentary photographs, using them as intellectual objects to depict her native city of Warsaw in ruins. Caught between past and present, she took on the responsibility of actively engaging in socio-critical photojournalism. Żarnower investigated the functions of image as rupture and redemption, building a fragmentary archive taking the form of an anti-war book.

\section{Results}

\subsection{Teresa Żarnower's Paradigm Shift: From Sculpture to Photomontage}

Teresa Żarnower was born in 1897 in Warsaw into an assimilated Jewish family. Between the years of 1915 and 1920, she studied sculpture at the Warsaw School of Fine Arts with Edward Wittig, who completed his education in Vienna and Paris himself, which strengthened and shaped Żarnower's artistic receptivity and open minded stance later on, when venturing oversees. Żarnower was comprehensively educated, especially in the fields of art, literature and philosophy. Her aptitude in languages enabled her to easily participate in European intellectual circles (Morawińska 1991, pp. 368-69). Throughout the interwar period, within existing international artistic networks, factions of Jewish artists often formed (Malinowski 1987, pp. 50-51). In 1923, the artist participated in the New Art exhibition in Vilnius with her leftist partner Mieczysław Szczuka (1898-1927). The same year, the pair exhibited in Herwath Walden's Galerie Der Sturm in Berlin, re-shaping German expressionist trends following The First Russian Art Exhibition at Gallery van Diemen, a highly influential exhibition that took place one year prior. With her abstract sculptures, Żarnower was one of over thirty female artists shown by Herwath Walden in his gallery during the years from 1910 to $1930 .^{3}$ Żarnower was also an influential figure in her home country. Indeed, Żarnower's apartment in the Leszno district of Warsaw became a meeting place for students to discuss modern art (Baranowicz 1975, pp. 97-98). These meetings produced the first canonical Polish constructivist group, the Blok of Cubists, Constructivists and Suprematists in 1924, as well as the eponymous journal that Żarnower and Szczuka edited, which became a creative enterprise for the couple (Król 2002, p. 349). The magazine was in print until 1926 (in total eleven volumes were published), "turning into [a] means of cultural, social and political Polish propaganda expression" (Vattano 2018, p. 1164). Photographic illustration and photomontages started to appear regularly in the pages of Blok from its second issue onwards.

Żarnower also took part in Blok group exhibitions in March 1924 in the Warsaw Laurin \& Klement's car showroom, and at the turn of 1924/1925 with the Polish Artistic Club held at the Polonia Hotel in Warsaw. The next year she exhibited at the International Art Exhibition in Bucharest (1926), as well as the International Modern Architecture Exhibitions in Warsaw (1926) and Moscow (1927). After the tragic death of her partner Szczuka in 1927 while mountaineering, Żarnower took over as editor and publisher of his magazine Dźwignia [Lever], (Berman 1965, pp. 100-9), which was inspired by the Soviet LEF journal. At that time Żarnower withdrew from artistic activity. In 1937, she migrated from Poland

3 Press Release, Storm Women. Women Artists of the Avant-garde in Berlin 1910-1932, at Schirn Kunsthalle Frankfurt, 12 October 2015: https://www.schirn.de/en/magazine/context/storm_women_women_artists_of_the_avant_garde_in_berlin_19101932/. 
to Paris, where the outbreak of the Second World War trapped her until 1940 and forced her into permanent exile. Adrian Anagnost suggests that after the death of military leader Józef Piłsudski in 1935, a rising atmosphere of anti-Semitism emerged in Poland-a potential explanation forŻarnower's flight to Western Europe (Anagnost 2016, p. 45; Zimmerman 2003, pp. 19-20).

Zarnower was an advocate for the utilitarianism of the machine: promoting collective work, rejecting individualism and insisting on entirely modern constructions (Mansbach 1999, p. 119). As a constructor of the new world, she was soon to face the destruction of her own work. Driven and influenced by the news and events in Europe during the Second World War, she continued to produce work on wartime Poland while living in New York from 1943 until her death in 1949. Among her major works are her cycle of photomontages for the book The Defense of Warsaw, which she created while in exile in Paris, and a monumental bas-relief sculpture devoted to the Warsaw Ghetto uprising in 1944, which was started in New York and never completed.

\subsection{Disarming the Military Manipulation: Żarnower's Frieze of Death}

The Defense of Warsaw (Figure 1) was published by the predominantly Jewish-Polish Labor Group in New York, depicting the destruction of Warsaw by German forces in 1939 . The $15 \times 22 \mathrm{~cm}$ book consists of 61 pages and eight plates of photographic illustrations: among them are three montages by Teresa Żarnower within the book itself and two additional photomontages are featured on the front and back covers (Rypson 2011, p. 111). The publication was printed as a paperback, on low quality paper and without color to limit production costs (Turowski 2000, pp. 216-17). In The Defense of Warsaw, Żarnower takes on an agitational narrative voice by drawing attention to the visual power of the photographic image and the enhancement of its strength based on the image's location in a sequence, as well as the form of a book. As an editor herself, Żarnower was aware of the possibilities of using foldout pages and die cuts to engage a reader.

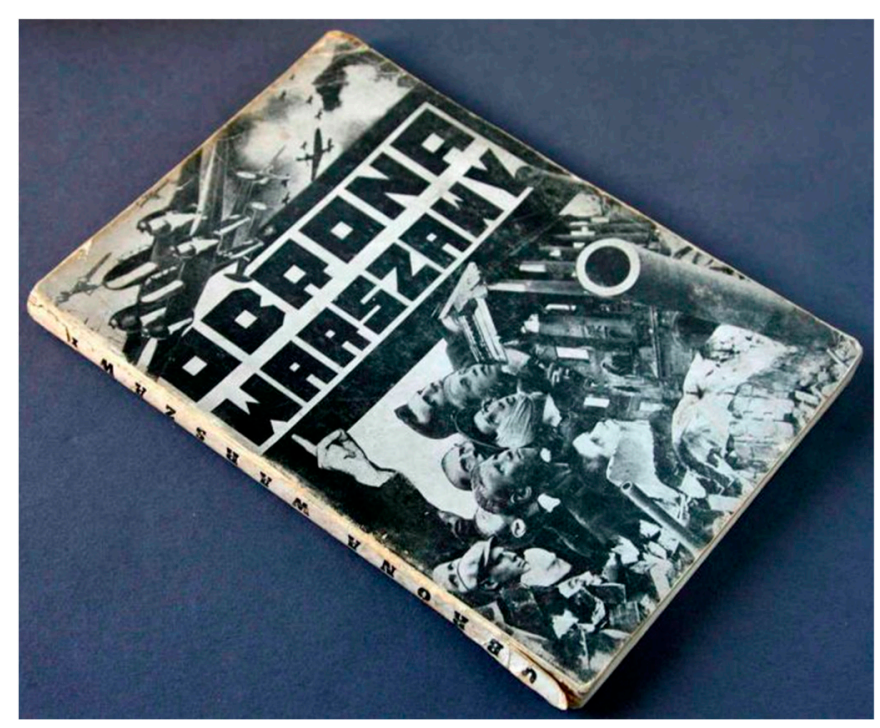

Figure 1. Obrona Warszawy. Lud Polski w Obronie Stolicy (Wrzesień 1939 roku) [The Defense of Warsaw. The People of Poland in the Defense of the Capital (September 1939)]. Polish Labor Group, New York, 1942, First Edition, Medium: book, Format: $15 \mathrm{~cm} \times 22 \mathrm{~cm}$, courtesy of On Paper Store, Italy.

The text accompanying the photomontage series Defense of Warsaw consists of a personal account, written by Zygmunt Zaremba (1895-1967), of the days that the city of Warsaw was under attack and occupied by the German army in September 1939. The book was printed twice prior to its release in the United States: the first edition was published in Warsaw, and the second in London. However, Zaremba's name was censored from the Warsaw and London editions for safety reasons. Yet, in the version printed in New York, the recto side of the title page lists Teresa Zarnower's 
name as responsible for the layout of the photomontages and illustrator. In sum, this book is a critical artistic product enabling an entire set of photographs to be revealed to the American public. Besides Żarnower's own work, it included photographs of Warsaw taken by anonymous authors during the first days of the Siege.

The photographs were as follows:

Warsaw after Bombardment: Castle Square

Warsaw after Bombardment: Street in the City Center

Warsaw Inflamed

Building of The Worker in Warsaw, Demolished by German shells

Graves of Warsaw Defenders in the Garden of Ujazdowski Hospital

(Idzior 2014, pp. 112-13 in Ślizińska and Turowski 2014)

Żarnower's work interferes and comments on the close proximity between interwar Polish graphic design and military imagery. The relationship between illustration design and war was ubiquitous in the Polish interwar period, as seen in the remarkable "military spirit" of the mainstream press, which provided daily commentary on Poland's international situation after "the country's borders were hacked out by force of arms after the First World War" (Rypson 2011, p. 344). Military iconography depicting the army and national defense was a "staple of current events" and occupied a prominent place in Polish graphic design. Although the image of the army as a political power structure was a central component of visual propaganda in the 1930s that fulfilled demands for an aura of modernity, it culminated in doing "the Polish state a very bad service, recklessly building the myth of a powerful army, capable of providing a rapid victory over an aggressor already preparing for war" (Rypson 2011, p. 346). The beginning of the Second World War saw brutal attacks on Poland from Germany on 1 September 1939 and from the Soviet Union on 17 September 1939 following their secret agreement to the Ribbentrop-Molotov Pact of 23 August 1939 regarding the division of Poland between the two countries. It was in this climate of September 1939 that Żarnower continued to pursue her agitational design work, while simultaneously joining the Government of the Polish Republic in Exile in Paris, which was operational from 1939 in the French capital and subsequently relocated to Angers until 1940, followed'by London until 1990.

Zarnower reintroduced the dimensions of narrative as presented in textual memory by Polish Socialist Party member and writer Zaremba in a September 1939 publication, which outlined the heroism displayed in the embattled city of Warsaw. In his open call on the 27th of September, Zaremba announced (originally in Polish):

People of Warsaw!

We stood up to fight for the freedom of the Capital City and the freedom of Poland with full faith that stopping the invasion at the thresholds of Warsaw would allow us to organize and order the armed forces of the Republic of Poland in the remaining free areas.

The heroic defense of Warsaw became a symbol of our loyalty to independence, it became a visible sign for the whole world of our readiness to give every sacrifice that is possible.

The bloodshed, the ruins and the ruins of the Capital will always testify to our will and our right to free state life.

The three-week defense of Warsaw, full of the generosity and heroism of the People and the Army, unknown to the world, did not bring the expected military results. Warsaw remained an island within a bilaterally flooding stream of foreign troops. All rumors about the coming help turned out to be untrue. At the same time our elementary devices were destroyed, and above all we were deprived of water. 
We faced the possibility of the total annihilation of the Capital and its people without any hope of expanding our defense.

Warsaw has succumbed to violence. We lost this battle. However, the day will come when the triumphant violence will collapse. We lost this battle with honor, and this fact will solidify us in the future, and will definitely burden us with the future world order after the war.

Now all we must do is to continue to maintain the internal consistency that allowed the working class to overcome the invasion and today will create a stronger foundation for future victory.

Let us master all reflexes of anger and regret. Let us not allow ourselves to be provoked! Let us keep the seriousness and tranquility of such a tragic moment.

We call on you Workers and Intelligentsia to do this. The P.P.S. called you to it, which until now has only called for a violent fight. Because to keep our sobriety and calm today also means to build the discipline we will need for the moment that must and will come to have a decisive meaning.

Via the cut-and-paste technique in The Defense of Warsaw, Żarnower redirected her focus into photography, a medium which had until then remained largely unexplored by Polish avant-gardists, apart from Stefan Themerson (1910-1988) and Janusz M. Brzeski (1907-1957). The development of "activist documentation" such as those explored in "reportage" and "social photography" or other class-conscious photography movements did not take place in Poland at all-while the opposite occurred in the Weimar Republic and the USSR (Witkovsky and Demetz 2007, p. 127). Thus, in her interpretation of the great events of her day, Żarnower contradicted the public Polish government's propagandist rhetoric by depicting the seriality of agony in the images of war in her agitational montages. This is especially prevalent in The Defense of Warsaw series.

For the photomontage on the book's cover (Figure 2), Żarnower placed a cut-out of a photograph of Warsaw's Palace of the Ministry of Revenues and Treasury on Rymarska Street, represented only by the building's Corinthian portico columns, which recall romanticized antique ruins, pasted diagonally with the tension drawing to the left. Three tanks composed into a triangle arise from the rubble in the lower right part of the photomontage, creating the skeleton of a distorted rhombus together with the Palace columns. In contrast to the Palace's derelict and collapsing columns, the tanks in the first plane of the photomontage seem intact and ready to fire. The central and largest tank placed directly in the right corner gives the impression of an immediate, direct explosion towards the viewer. As Adrian Anagnost noted: "Across a variety of media, Żarnower's works display tensions between monumentality and fragility, between rupture and the persistence of tradition, between annihilation and renewal" (Anagnost 2016, p. 38). The tank points its barrel upwards to the left hand side of the photomontage, where a montaged hand points its index finger towards the sky filled with warplanes. Underneath the planes lies the title of the book, written in Polish: OBRONA WARSZAWY, the two words placed one on top of the other. The arm with the pointing finger (the leitmotif in Żarnower's 1920s agitational photomontages) cuts into the title's black borders perpendicularly—written in black font on a white background. Via its wings and engine, the airplane in the upper left corner plays the role of connecting the first three letters of the word 'obrona' [defense], thus breaking the title's frame, meaning the line of the frame seems to stem from the engine. The airplane is flying towards the upper left corner as if it wanted to leave the cover altogether, therefore creating a feeling of constant movement within the space of the photomontage. The elements of the tank in the lower right corner merge with one of the leftward-falling columns of the Palace, creating a diagonal line which joins with the leftward-flying plane. A crowd of human beings is represented by the heads or busts of predominantly young boys gathered together in the lower left corner, who are looking up towards the sky filled with warplanes and gazing in the direction of the pointing finger. Around ten faces are represented, matching the number of planes, whose shadows are cast in the upper right corner. 


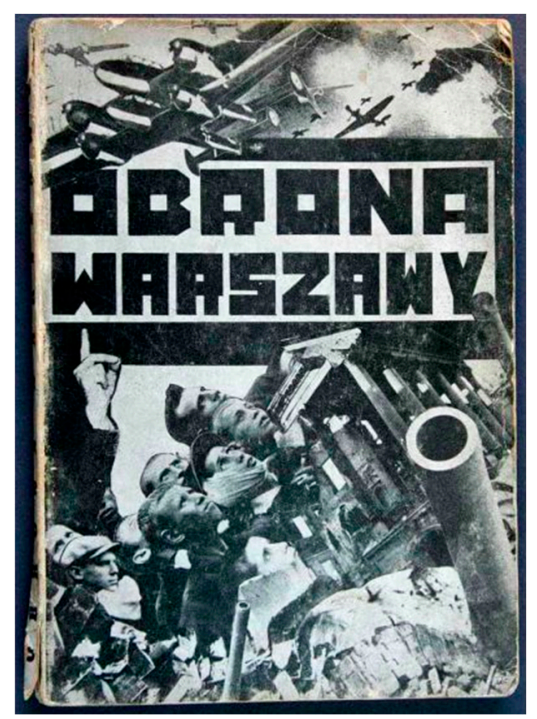

Figure 2. Teresa Żarnower, front cover of the book The Defense of Warsaw. Polish people in defense of the capital (September 1939), Format: $15 \mathrm{~cm} \times 22 \mathrm{~cm}, 1942$, courtesy of On Paper Store, Italy.

The composition is forged and founded on the measured calculations of numerous elements, which are combined in groups and with three individual motifs: the tank on the right, the pointing finger on the left and the singular large aircraft situated on the upper left side. The composition is dominated by the title text located in the upper central section of the page. The exceedingly complicated montage is stabilized by the effect of the rectilinear merging of the text, a technique which Żarnower had previously utilized back in the 1920s with her creative partner Mieczysław Szczuka. Scholar Bożena Lewandowska picked up on Żarnower's ability to develop "a certain type of cover, characterized by geometrized lettering and the simplicity of vertical-horizontal divisions", as seen in the Lenin, Liebknecht, Luksemburg photomontage for the magazine Czerwony Sztandar (Figure 3) and also through the juxtaposition of white, black and red planes, as seen in her previous photomontage Europa, 1929 (Figure 4) (Lewandowska 1966, pp. 254-55). The crowd of people in The Defense of Warsaw cover page blends with the façade of the ruins. The facial expressions are recognizable and helpless, full of despair and resignation; one boy's head is clearly injured and is depicted covered with a bandage. Another figure, positioned in the lower middle section of the photomontage, appears to be wearing a neck brace at first glance. However, upon closer inspection, one can make out that his head is merging with the rubble.

The composition of the second photomontage on the back cover (Figure 5) is dynamized by contrasting slants. The viewer experiences larger close-ups without clear geometric divisions of three-dimensional space made up of photos placed one on top of the other, combined into one photographic composition. The scenes from this photomontage are modeled on a film strip showing another section of the ruined city. The largest section of the photomontage is devoted to an upturned cart bearing two figures, whose faces wear familiar expressions of lament. They are covering their faces with one hand, as in Käthe Kollwitz's 1938-1940 bronze Lament. In the cart, the corpse of a man lying face down, his right hand hanging torpidly, provides a total opposition to the first cover where the hand is outstretched, pointing upwards towards the sky. The scene shows the aftermath of the bombardment, down on the ground. Beneath the cart there is a smaller corpse lying in a vulnerable position: a child laying on his/her back with wide-opened arms, outstretched to the sides and their visible facial profile turned towards their right arm. The body is depicted laid out on a hill, thus dynamizing the corpse's posture. The torso is leaning down the hill towards the viewer. Just next to the hanging hand, closer to the left corner of the montage, figure of a sobbing boy sitting on some rubble with his head cradled in his arms embodies a feeling of despair. Figure is placed in the foreground, but simultaneously is away from the central scene (Turowski 2000, p. 218). The boy in question is nine-year-old Ryszard Pajewski, sitting atop the ruins of his house in the Praga district of Warsaw after the Luftwaffe raid, 
as photographed by Julien Bryan, who described him as follows: "Ryszard Pajewski, when I saw him sitting on a pile of rubble, was the epitome of dejection and sorrow. He was only nine-year-old, and had just become the primary breadwinner of his family — but food was scarce". 4 In the middle of the photomontage, behind the cart with the corpses, Żarnower depicts tradition defeated by technology via the image of King Sigismund III Vasa's toppled column in Castle Square. Vasa established Warsaw as the capital of Poland. As in the first photomontage, in which Warsaw's Palace of the Ministry of Revenues and Treasury leans towards the left, here, King Vasa's column tips towards the right. The face of the shocked girl pasted in the upper left corner dominates the entirety of the composition and her incredulous disposition stays with the viewer. The left side of this reverse cover photomontage is plastered with cut-out photographs of ruined façades: brick constructions are dotted with the empty black holes of broken windows.

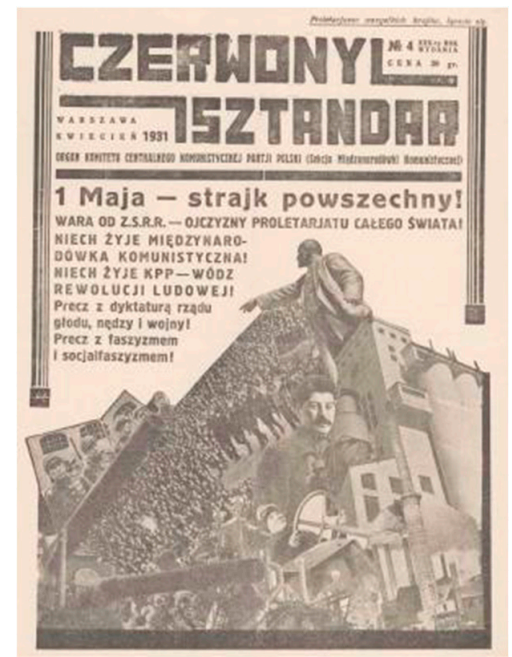

Figure 3. Teresa Żarnower, Lenin, Liebknecht, Luksemburg, photomontage in Czerwony Sztandar (Red Flag periodical), 1931 , no $1,30 \mathrm{~cm} \times 22.5 \mathrm{~cm}$.

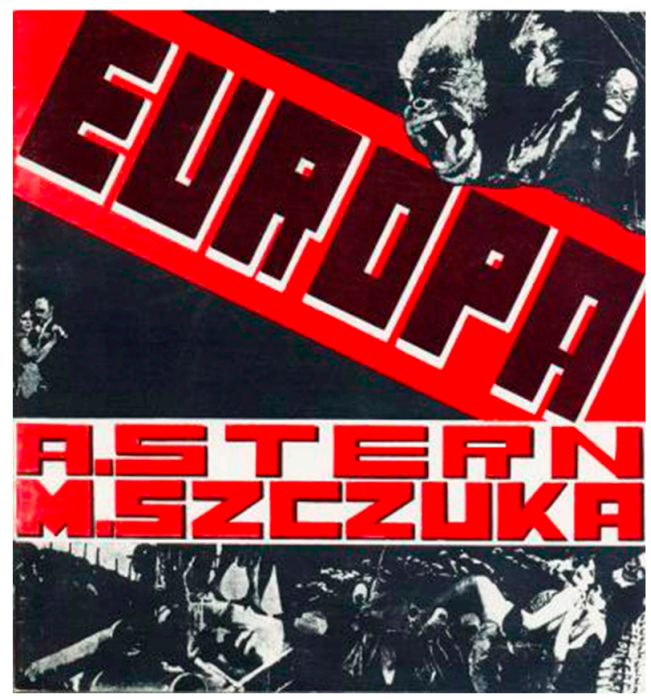

Figure 4. Teresa Żarnower. Cover design for poem Europa by Anatol Stern, 1929, Muzeum Sztuki in Łódź, public domain image.

4 United States Holocaust Memorial Museum \# 31324, Julien's Bryan's gift, no. 8 of 19, In: Teresa Żarnower (1897-1949). An Artist of the End of Utopia, eds. Ślizińska, Milada and Andrzej Turowski, Muzeum Sztuki in Łódź, 2014, 117. 


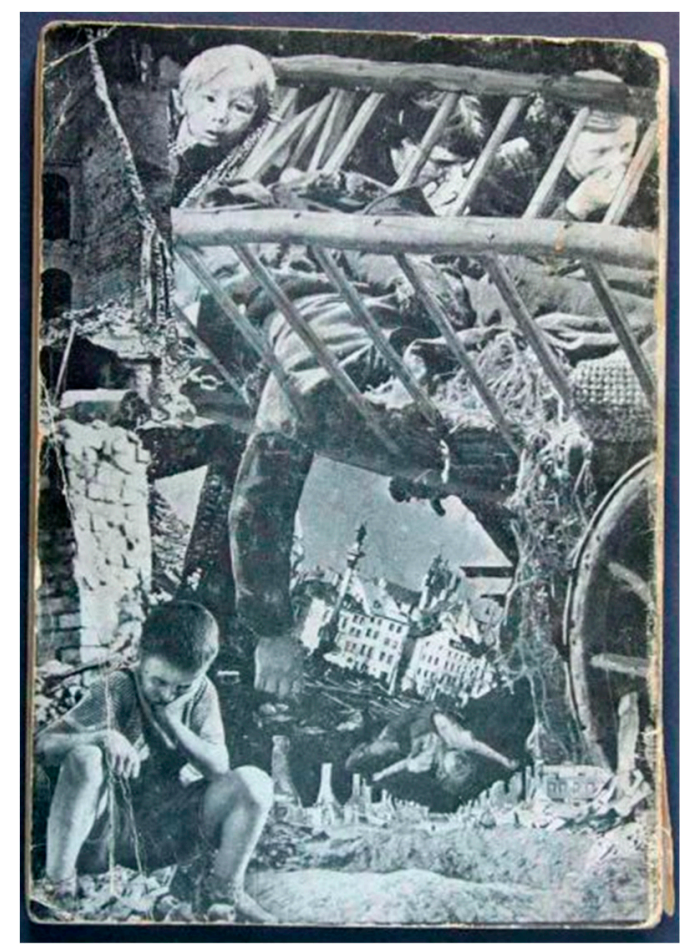

Figure 5. Teresa Żarnower. Obrona Warszawy (Defense of Warsaw) (1942), photomontage (back cover of book), courtesy of On Paper Store, Italy.

The opening series of photomontages inside the book (Figure 6) is composed of photographic portraits representing politicians. In the middle is Stefan Starzyński, who served as President of Warsaw both prior and during the siege. Starzyński was contacted by U.S. photographer, documentary filmmaker and writer Julien Bryan (1899-1974), who requested a permit to photograph and document Warsaw between 7 September and 21 September 1939. He travelled to Warsaw with a Leica still camera and a $35 \mathrm{~mm}$ Bell \& Howell motion-picture negative-and upon his return to New York-assembled the footage he captured into the ten-minute newsreel or short documentary film Siege (1940) which was released by the Radio-Keith-Orpheum (RKO) company, featuring in its Realism Series. One year later, the film was nominated for an Oscar in the one-reel category for the best short subject (Idzior 2014, p. 130 in Ślizińska and Turowski 2014). Bryan's photographs were published in the biweekly Look Magazine. The Special War Feature section of issue 10/1939 of the magazine, entitled Can Hitler's Lightning Do This to England? (pp. 10-13), presented the photographs documenting Germany's attack on Warsaw. As their headlines suggest: Inside a Hospital During an Air Raid, These Are the Faces of War and the infamous Sister, Why Don't You Speak? series portray 12-year-old Polish girl Kazimiera Mika, mourning the death of her 14-year-old sister Anna, who was killed in a field near Warsaw during a German Luftwaffe air raid. In her photomontages, Żarnower also consciously chose to portray recognizable and known figures. Furthermore, in many of them she explicitly singled out and utilized the reprints of Bryan's photographs.

In the photomontage, a photograph of Mieczysław Niedziałkowski can be found on the left hand side—a member of the Polish Socialist Party—as well as Maciej Rataj—a member of the Polish People's' Party "Piast" - who is presented on the right hand side. All three men stayed in Warsaw during the Siege and took part in the Citizens Committee for the Defense of the Capital. Niedziałkowski and Rataj were both arrested by the Nazis in 1939 and executed in Poland during the German AB-Aktion (Außerordentliche Befriedungsaktion (extraordinary operation of pacification), which aimed to eliminate the Second Polish Republic's intellectuals and upper classes across the territories slated for eventual annexation (Piotrowski 1998, p. 25). As for Starzyński, his fate remained uncertain, but the Dachau concentration camp, the potash mine in Baelberge, a Spandau prison or the Warsaw Uprising were 
a few of the many possibilities discussed concerning his execution. Żarnower and other editors, already feared the worst with regards to Starzyński's fate when The Defense of Warsaw was submitted for printing back in May 1942 in New York (Idzior 2014, p. 117 in Ślizińska and Turowski 2014). The three characters are positioned against a wall representing the exact site where many of Warsaw's defenders were executed. On the wall hangs a frayed Polish Socialist Party poster: a clear nod to the city's defenders' political orientation. The wall is placed diagonally, leaning to the left. In the upper left corner, an arrow can be seen plunging into the wall guiding the direction of movement within the photomontage. The photograph of Maciej Rataj in the lower right corner captures his left profile, gaze to the left and following the direction of the arrow. The arrow has a cut-out triangle. Again here, Żarnower makes use of a geometric approach and relies on multiple visual repetitions, such as between the three angles of the triangle and the three heads of the politicians.-With its thick black line, the arrow frames the outline of the wall as well as the three political figures who are placed against its empty white space-harking back to the way the title is framed on the front cover of the book. In a sense, these three men were responsible for the defense of Warsaw, thus, their function fully aligns with the meaning of the title. The Polish government representatives are dressed in suits and ties, which contrasts with the crowd of anonymous people represented in the first two photomontages, clad in casual clothes.

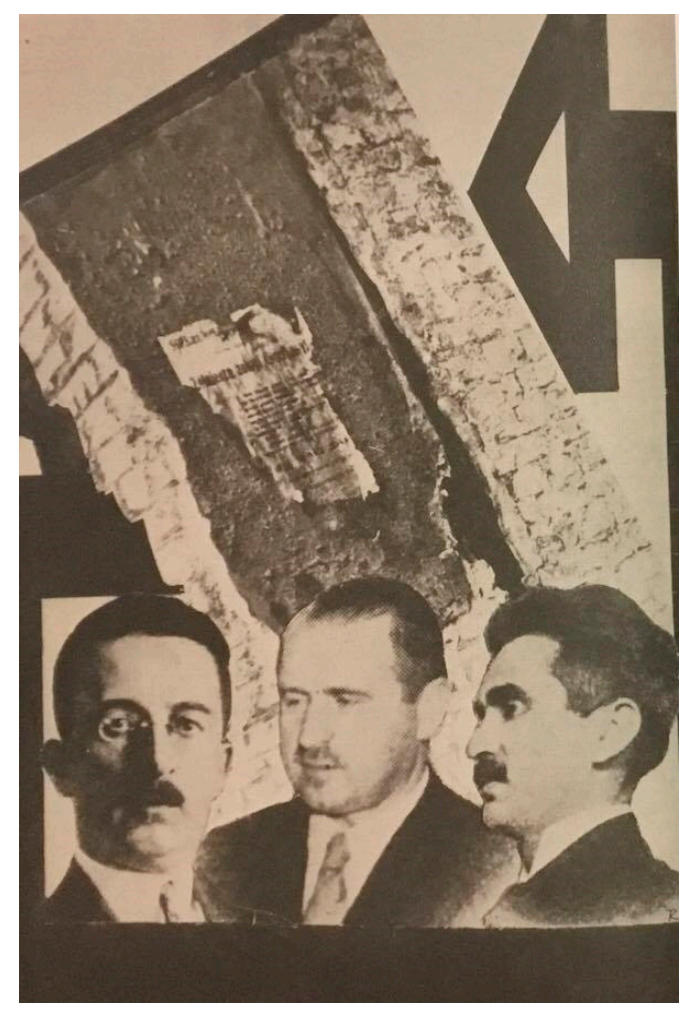

Figure 6. Teresa Żarnower, The Defense of Warsaw photomontage: The leaders: Niedziałkowski, Starzyński, Rataj, 1942, Muzeum Sztuki, Łódź, public domain image.

Strikingly, the figure of nine-year-old Ryszard Pajewski featured on the back cover reappears in the photomontage entitled In the days of terror (Figure 7), however, this time he is not placed in the foreground. He disappears among other figures from various photographs making up the entirety of the background. In this case, his pensive attitude recalls Rodin's The Thinker, 1902. He appears to be meditating over the hundreds of people portrayed the montaged photographs at the moment of their executions. An execution scene is depicted in the lower central photograph-and above it, a representation of Polish women being deported to the Palmiry forest close to Warsaw. The group of people found in the lower right hand corner are symbolic of forced labor, which is demonstrated 
their requirement to not only dig the graves of those already executed, but also their own (Idzior 2014, p. 131 in Ślizińska and Turowski 2014). Seemingly out of their backs, emerge a larger pair: a woman and a young girl (mother and daughter?) with scared faces, closely followed by German police and SS officers behind them, who are laughing and in the process of cutting off an Orthodox Jew's beard. Other pictures feature additional degrading mass executions: people lined up against a wall awaiting the firing squad. The upper-middle photograph shows a ship surrounded by large crowds: a symbol of escape. There are two ladders in the upper left hand photo leaning against a ruined façade. These scenes, wrapped in black square frames, seem to encircle Ryszard Pajewski. Here, Żarnower introduces the concept of accumulated photographs "to measure separate perspectives and sudden jumps in the scale of overlapping photographs" (Czekalski 2000, p. 129). Żarnower recounts the story, "seen as if from afar on single frames of a film", filled with shooting scenes, the horror experienced by women and children, mass murder, Jews with yarmulkes and amused Wehrmacht soldiers. The background for these scenes is the city in ruins (Turowski 2000, p. 218). Here, montage fulfils its primarily mechanized purpose by being "based on the photograph as protocinematic prosthetic of urban vision" (Stierli 2018, p. 3).

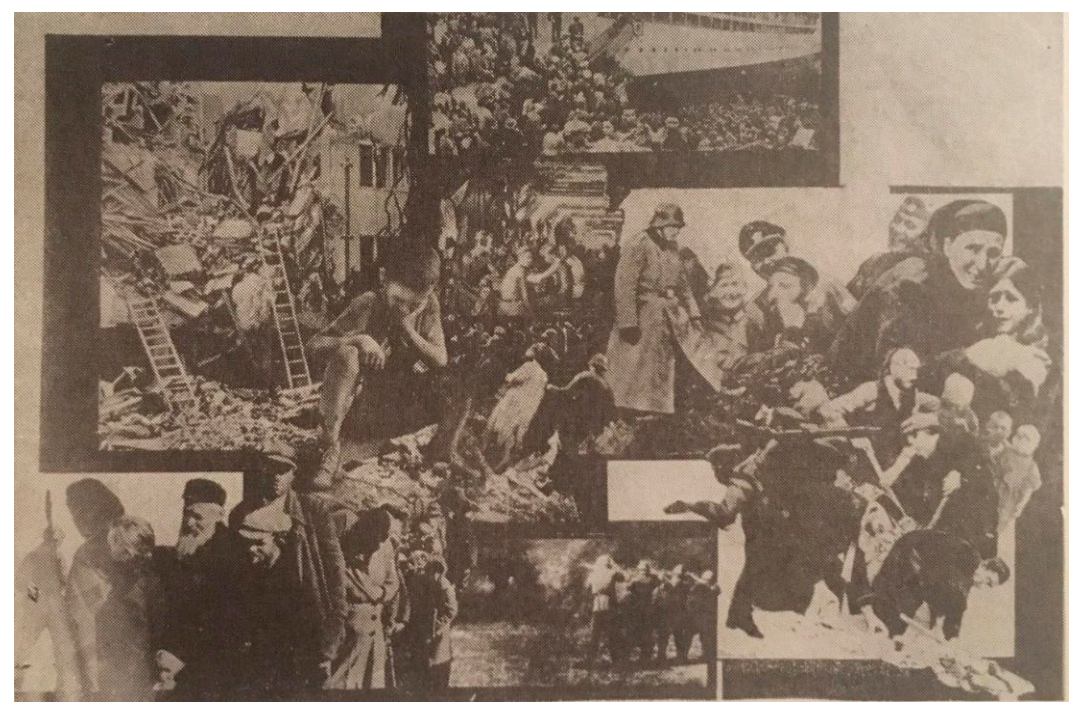

Figure 7. Teresa Żarnower, In the days of terror (1), photomontage from the book Defense of Warsaw, 1942.

The next photomontage (Figure 8) of the same title zooms into larger close-ups. The narrative focuses on the consequences of the massacre committed in the previous photomontage. Here the composition is divided in a similar way to the cover photomontage. The bottom left corner of the space is dynamically composed into the shape of a triangle that culminates in figure of a man holding a little girl in his arms. The pair are entangled in wire. Behind the man's back, in the left part of the photomontage, the body of a baby appears also wrapped in the wire, but with its head touching the black frame. Beneath it on the lower left hand side, figure of woman covering her face with her hands and crying over the corpses of a couple is depicted. The man's body is draped on top of a second woman, who is lying on her back, enabling us to clearly see her facial expression: a scream. The man embraces her head with his arms. The two figures are flanked by the legs of a man whose head is not visible. When it comes to decisions on figures, Żarnower keeps the selection cross-gendered and cross-generational in civilians' representation, visualizing and mediating the scope of war consequences. The right hand section of the photomontage is divided up using two grids, marked by thick black lines, as has been already repeatedly observed in the previous photomontages through the use of framed photographs, arrows, and the borders around the title. Thus, through its graphic design and relation to other narrative elements within the layout, such as crosses on graves above a photograph of the ruined city in the lower grid, the line functions as an informational and emotional device. The clearly discernible singularity of the four crosses erected in the middle of the road, as a replacement 
for a graveyard, backed by an empty and foggy city scape contrasts with the lower grid filled with accumulated ruined and gaping building facades, a mass of small figures, over which Żarnower has imposed bent gutters that splay out over the frame which is defined by the thick black line. In the upper grid the right hand side of the rectangular frame is omitted, while in the lower grid the base of the rectangle has also not been added. The viewer's visual journey during perception leads the eye towards the continuation of open estuaries due to the lack of framing at the bottom and to the right of the page. In the book, this photomontage was positioned as cropped to the left enabling the two right hand side photomontages to sit at the top of the page.

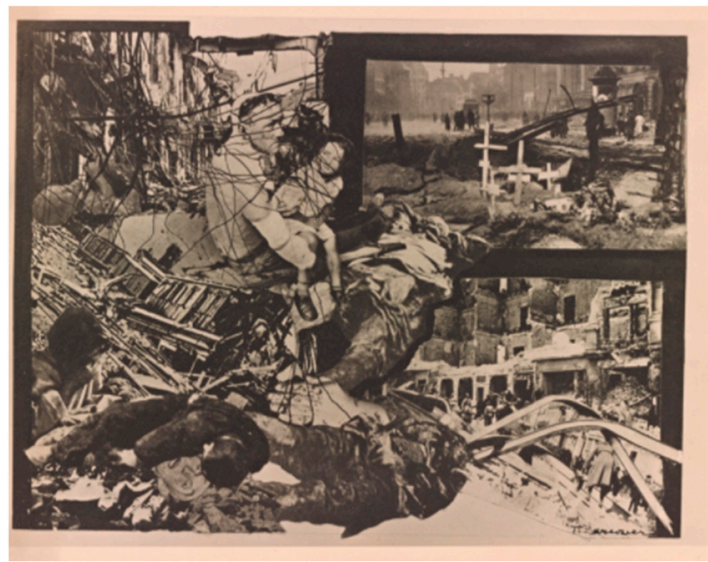

(a)

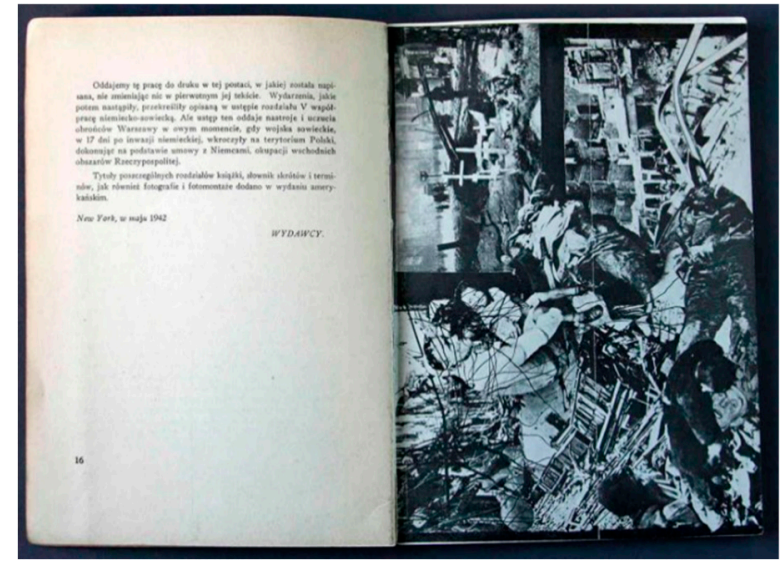

(b)

Figure 8. (a) Teresa Żarnower, In the days of terror (2), photomontage from the book Defense of Warsaw, 1942, The New York Public Library, public domain image; (b) Teresa Żarnower, In the days of terror (2), photomontage in the book Defense of Warsaw, 1942, courtesy of On Paper Store, Italy.

In On the road to death (Figure 9), the last photomontage, Turowski notes: "There are no codes or divisions. There's no distance. This is one big picture of wandering and death" (Turowski 2000, p. 218). Nevertheless, in the midst of fire, dust and smoke on the road in the foreground, numerous corpses form the base of a triangle. Its sides are built from the line of living people walking from the left hand side of the photomontage into the background, towards the depths and the cluster of ruined houses, which simultaneously provides the starting point for figures walking in the opposite direction, towards the front, on the right hand side of the triangle. Wandering people rotate on the sides of a triangle that begin and end either with ruins or gathered piles of corpses. In the lower right corner, a man's two-wheeled trolley meets a dead person's naked legs, the right one bandaged up. As on the back cover of the book in the image with the people lamenting in a cart, two hysterical figures appear on the left hand side of this photomontage, emerging from the ruined houses. The first figure from the left is a woman with her head in her hands, crying over the damage, and the next one is a man standing in a white shirt with his hands on his head expressing huge disbelief at his current situation. The cropped image is bordered by a brick wall. To contain this mass of visual information, Żarnower framed the photomontage through an architectural feature of the ruined city, which became a firing trap. The visual challenge involved when reading this series in The Defense of Warsaw lies in the fact that the two photomontages on the covers (and the one inside representing the politicians) and two other photomontages in the body of the book, differ dramatically in their inner visual compositions. The covers overlay sequences of cropped images to narrate the events in Warsaw. The two inside take the form of first-person narrative with a focus on "reportage" documentation, and simultaneously encapsulate the consequences of the invasion and devastation.

Żarnower concisely conveys the formulas of 1920s constructivist design by incorporating elements of geometric structure, a principal diagonal axis, spatial perspective, and through the conception of the book as a visual narrative. Additionally, the book also has an almost cinematic disposition. 


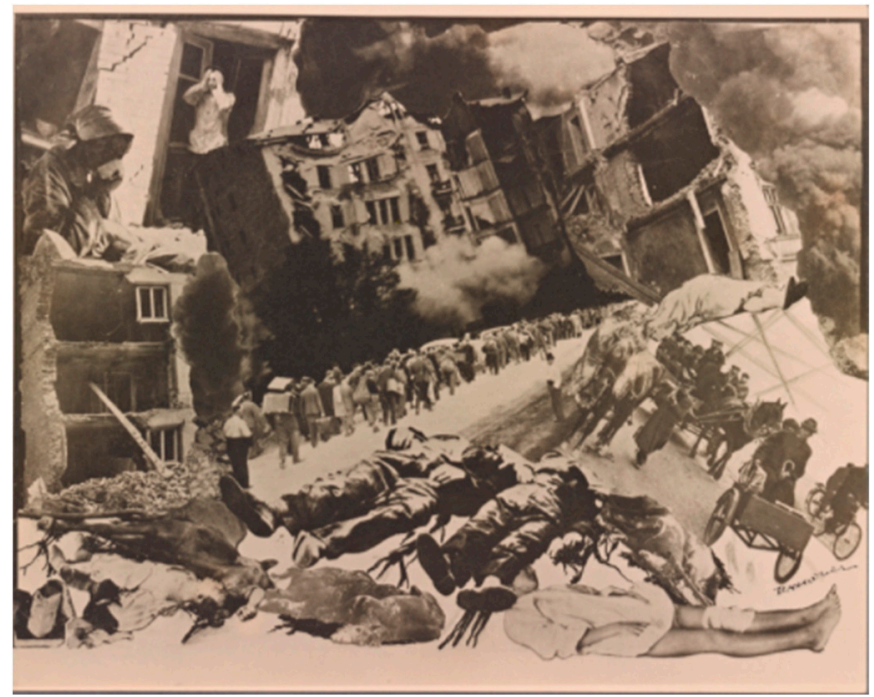

Figure 9. Teresa Żarnower, On the road to death, photomontage from the book Defense of Warsaw, 1942. The New York Public Library, public domain image.

In the manifesto entitled, What is constructivism? published in September 1924 in a double issue of Blok (No. 6-7) and signed by Żarnower and Szczuka, the pair attempted to provide an answer to the title question. They declared that constructivism can be defined as: "A matter of STRUCTURE and not a matter of form. ( ... ) The channeling of creative endeavor primarily into construction, cinema, printing and the so-called fashion world. (... ) INDIVISIBILITY OF ISSUES DEALT WITH BY ART AND SOCIAL ISSUES". Thus, both Żarnower and Szczuka noticed the unique abilities of photographic illustration to construct and mediate the reality around them to the public. These artistic and social principles relied on modernist culture framed by socialist utopias to fuse formal and utilitarian concepts aimed at a proletarian audience (Ślizińska and Turowski 2014, pp. 171-75). Żarnower's archive presents a range of photographs in the photomontage entitled In the days of terror, which can be likened to the technique El Lissitzky (1890-1941) employed in his Photo-Frieze in the Soviet Pavilion at the International Press Exhibition in Cologne in 1928. Together with Sergei Sen'kin, both Russian artists titled one of their photo-lithograph photomontages: The Task of the Press is the Education of the Masses. Five years later, in The Topography of Typography, Lissitzky referred to "The continuous-page sequence-the bioscopic book" revealing his stance as favoring the modern medium of cinema and the photographic material used in the editing of documentary films.

Indeed, Żarnower herself has also been compared to Russian avant-garde artist Natalia Goncharova (1881-1962) through the idea of sculptural exploration in terms of the interpretation of the body by its surroundings. The comparison to Żarnower's photomontages is evident when taking a closer look at Goncharova's fourteen linocuts Mystical Images of War from 1914, which served as accompaniment for Kruchenky's poems. This is especially apparent in the Angels and Airplanes linocut which can be likened to Żarnower's cover photomontage in its "dynamics, rhythm, and mass gesture", further "spelling disaster and destruction". Both Goncharova and Żarnower were directly inspired by the impact of a singular day. Both applied "stringent documents [with regards to the] quality of newspaper chronicles", exemplifying tragedy (Gurianova 2012, p. 176). According to Gurionvoa, in Mystical Images of War, Goncharova did not merely imagine the insights and events of the war, she "mimicked the mass reaction to war, as reflected in the religious symbolism that saturated contemporary Russian newspapers, journals and postcards" (Gurianova 2012, p. 173). On the other hand, Żarnower's photomontages, mostly rooted in circulating reprinted photographs to various foreign press magazines are, nevertheless, stripped of mysticism, resulting in the production of fairly factographic and less avant-gardist sequential images of war. 
Goncharova delved into folklore, children's art and the inexpensive, then popular print form of lubok from native Russia, blending "realistic renderings" (Suzuki 2004, p. 79), while Żarnower utilized a combination of all the known modernist devices of constructivist typography and new printing technologies to create strong nuance in the black and white of her photographs and photomontages. The composition of Angels and Airplanes linocut is founded on the contrast between the two colors blocks of black gouache and white surface, whereby the carved contours of the forms are rendered in black and the background of the image and unprinted section remains bare. The geometric wings of the two planes form a zigzag, with the first one intersecting the linocut at the axis line, traveling from the left corner up to the right, converging with the wing of the second plane. Zarnower's would also utilize the flat or long rectangular shapes and spaces for words, titles and slogans in her montaged posters. In Goncharova's linocut, the division of the surface into three triangles is made possible by the dynamic position of the wings. Each triangle possesses an angle filling the space and the frame is flooded by a light hue, unlike the black shades prominent in Żarnower's compositions.

\section{Discussion}

The early history of modern photomontage oscillates between Berlin dada and Soviet constructivism, while the interwar period of photomontage in Poland is lesser known. One of the two key developmental pathways of Polish photomontage is its transition from an avant-garde movement to a political activity, placing art in the service of Communist ideology and militant journalism. This was endorsed by Mieczysław Szczuka and legitimized by artists both in Germany (for instance John Heartfield) and in the Soviet Republic (with artists such as Alexander Rodchenko, El Lissitzky, Gustav Klutsis, etc.) (Czekalski 2000, p. 336). Szczuka and Janusz M. Brzeski were two of the key players working with the medium of photomontage in Poland at that time. Indeed, their concepts would then be picked up and further developed by Żarnower-and in particular, those introduced by Szczuka, who published a telegraphic manifesto entitled Fotomontaż (Photomontage) in Blok no. 8/9 in 1924:

PHOTOMONTAGE $=$ the most condensed form of poetry

PHOTOMONTAGE = PLASTIC-POETRY

PHOTOMONTAGE results in the mutual penetration of the most varied phenomena occurring in the universe

PHOTOMONTAGE-objectivism of forms

CINEMA - is a multiplicity of phenomena lasting in time

PHOTOMONTAGE-is a simultaneous multiplicity of phenomena

PHOTOMONTAGE-mutual penetration of two and three-dimensionality

PHOTOMONTAGE-widens the range of possible means: allows the utilization of those phenomena which are inaccessible to the human eye, and which can be seized on photosensitive paper

PHOTOMONTAGE— the modern epic.

In these nine simple statements, Szczuka favors the technique of photomontage to "interweave two and three dimensions, depicting phenomena unobservable by the naked eye with documentary verism and a cinematic sensation of simultaneity" (Witkovsky and Demetz 2007, p. 41). In Szczuka's manifesto, cinema exceeds the photomontage medium only once, through its ability to demonstrate a multiplicity of phenomena lasting in time. Early experiments with photomontage had a tendency towards the cinematic, as Poland was a nation rich in film theory. The concept of photomontage gained a "singular legacy to be made expressly to be filmed, films that dwell on photomontages, photomontages screened in the place of films" (Witkovsky and Demetz 2007, p. 38; Giżycki 1996, pp. 27-40, 77-100). 
In her factographic production for the series of photomontages The Defense of Warsaw, Zarnower takes this cinematic approach to the urban space. During her escape from Nazi-occupied France, she traveled accompanied by prominent avant-garde film artists Stefan and Franciszka Themerson, both close friends of Żarnower and Szczuka's. From their oeuvre, Żarnower mastered the method of applying a sequence of filmed photomontages and still photographs. Janusz M. Brzeski deployed an entirely different technique consisting of extending the view of a single photomontage. Zarnower's use of both photomontage and photography in the booklet The Defense of Warsaw suggests film as a form for both mediums, resulting in a flow in image reception when the viewer leafs through the pages. Each of her photomontages functions as its own entity, yet one can discern a clear intersection of "the subject in the perceptual and the mnemonic apparatus" (Buchloh 1999). The motion of the images and the spectator's mobility work together to create the "poly-perspectivalism of montage" necessary to understand a differing subjective perspective. A mass experience like war is bound to produce contrasting viewpoints and the subjectivity of a viewer generates "a collectivizing change". Thus, montage as a "system of representation based on flatness and the spatial adjacency of heterogeneous elements" creates a politically activated mass subject (Stierli 2018, pp. 268, 10).

The artistic decision to present the never-before-seen shock and agony that took place in Warsaw through the technique of montage demonstrates a conscious architectural understanding of spatial representation on Żarnower's part. As argued by Martino Stierli in Montage and the Metropolis. Architecture, Modernity and the Representation of Space, "the montage is a technique that is primarily urban, visual and spatial, addressing the metropolis and its architectural manifestations as phenomena that are negotiated first of visually" (Stierli 2018, p. 2). Furthermore, the use of manipulated photography and photomontage in architectural space became common practice for avant-garde architects, as part of their theoretical debate on suitability of photographic techniques in the architectural domain (Stierli 2018, p. 81). In Żarnower's case, montage provided a powerful tool to continue to foreground the experience of urban destruction. The cognitive value of vision was not directed towards an idealist cosmology, but more in the direction of living through the traumas, conflicts and hidden politics of everyday life in the industrial metropolis (Mertins 2001, p. 112). Avant-gardist photomontage, with its frequent inclusion and treatment of architectural and urban space fragmentation, became a consequence of the "shock" experienced by the modern metropolis (Stierli 2018, p. 32). Montage itself "is a consequence of the perceptual revolution brought about by the modern metropolis and seeks to visualize an (urban) reality not yet seen" (Stierli 2018, p. 14).

In interwar Warsaw, where motivation to rebuild was high after the end of Russian occupation in 1918, Żarnower herself took a position in architectural planning "informed by esthetic concerns and artistic practice as a visionary projection of future life" (Anagnost 2016, p. 41), in order to fill the gaps in the cityscape of Warsaw's metropolis, which had already been destroyed by Russian and German armies during World War I (Józefacka 2011, p. 8). Together with Mieczysław Szczuka and other Polish architects, Żarnower produced such architectural designs as: Static Constructions, Practical Applications and Cinema Project, in which she worked with the technique of axonometric projection, a concept that was developed in parallel to the photomontage technique:

Countering perspectivalism's determinism with regard to the location of the viewer, both photomontage and axonometric are characterized by their perceptual ambiguity or even indeterminability, and both tend to leave the viewer in the dark as to his or her own concrete position in space. The deceptive stability of representation in perspective is questioned and destabilized, confronting the perceptual apparatus with an irresolvable visual challenge. (Stierli 2018, p. 37) 
Following a study conducted by scholar Stan Allen, Stierli observed that axonometric projection equally involves both the mobile and placeless spectator:

If perspective, dependent on a fixed point of view, seemed to freeze time and motion, the atypical space of axonometric suggested a continuous space in which elements are in constant motion. The same property that made axonometric such a useful tool in explaining the construction of complex machinery or spaces ... could be exploited here to suggest the simultaneity of space and time. The reversibility of the spatial field allowed for the simultaneous presentation of multiple views.... Axonometric and technical drawings lend themselves to the manipulation of views in an effort to describe the totality of the object. (Allen 2009, p. 19)

The interaction of the spectator and the specific and intentional placement of constructivist objects are named by Buchloh as two of the main facets of faktura. Through the photomontages in The Defense of Warsaw's construction and built-in visual narrative sequence, Żarnower placed importance on engaged perception with the intention of spurring political action, while also keeping the process of representation incorporated in the visual messages of the war photographs. The process enabled these images to lead to "purely indexical signs" (Buchloh 1984, p. 90), so as to embed traces into the viewer's memory. Through different perspectives in Żarnower's photomontages—simultaneously dynamic and static - the spectator was given the necessary three-dimensional space to penetrate the fragmentary ruins and immediate history of the then still-ongoing World War II. As author of the documents and works, Żarnower urged a reaction via remembrance and memory.

During the 1930s, the endeavors of the avant-garde turned towards realism and proletarian art in the domain of political disputes, which in turn affected the field of photomontage. In his 1984 essay From Faktura to Factography, Benjamin Buchloh highlighted the relevancy of a paradigm shift within the Soviet avant-garde, addressing the modernist transition and moving from a focus on the individual viewer to a "simultaneous collective reception". This, he claims, was an inevitable consequence of the avant-garde's espoused intention to reach the masses. The trends that developed in the Soviet Union during this period were reflected in the work of left-wing artists, including artists in the neighboring country of Poland and predominantly in the city of Warsaw. As Buchloh indicates, the Soviet photomontage of the twenties was situated between "texture" and "factography", an attempt to reconcile the experience of the avant-garde when it comes to form, with the postulate of art set in reality and fulfilling the functions of propaganda. The most characteristic examples of Soviet photomontage during this period are the illustrations of Lissitzky and Rodchenko which can be found in USSR in Construction, a propaganda magazine published throughout the 1930s. In these works, the technique of assembling the photographs clearly contributed to the construction of a new theory of "historical realism". Both artists tended to idealize and monumentalize the "facts" in their work, due to the Soviet authorities' tightening of the cultural policy. Thus, when Rodchenko published in the White Sea Canal issue of USSR in Construction in 1933 (issue no. 12) or Lissitzky, in 1940 in the issue devoted to Western Ukraine and Western Belorussia, facts were omitted with regards to their productivist process. The former overlooked the deaths of thousands of prisoners during the construction of the canal, who were not portrayed as suffering, while the latter designed the layout for a fake story on Poles welcoming the Soviet occupation into the Eastern part of their country (Margolin 1997, pp. 186, 206).

In addition, by constructing The Defense of Warsaw photomontages, Żarnower's art was seemingly placed in the direct service of politics. However, instead she approached the Polish government's propagandistic rhetoric with a critical eye, presenting a version of the September 1939 Nazi invasion of Warsaw stripped of monumentalized heroization. The radical change of circumstances that occurred for Żarnower during the outbreak of the Second World War led her to cooperate more closely with the state and she demonstrated willingness to undertake the commissioned work. The Defense of Warsaw book preparation directly implicated Żarnower as active participant in the representation of Poland to the public both abroad and at home. Her factographic continuation of the interwar period differs 
from the one presented by productivist artists socially active in the authoritarian regime of the Soviet Union. When interpreting her materials, Żarnower preserved the postulate of pure factography, the art of documenting, leading to a preference for the book form, which born out of the idea of a form of reportage or film chronicle. Her war photomontages followed a methodology of juxtaposition of a multitude of photographic facts into one, all the while staying true to history and steering away from creating false memory. The shocking, raw and authentic imagery of war photography was a medium that resisted manipulation in her work. She did not use the technique of photomontage to idealize the tragic events, unlike the "historical realism" trend so dominant in the Soviet Union (Czekalski 2000, pp. 110-11).

The medium of photography constituted the only source material that did not require much creative and productivist reinterpretation. Żarnower's interventionist journalism could keep up with the dynamics of war representation and information dissemination. The ability to document the act of witnessing historical events is usually assumed to be the function of photography: its "ultimate purpose is to record history", and simultaneously, to insert the viewer into this history. Photography may intersect with history in diverse ways (Badger 2014, pp. 91-92). The indexical sign of documentary photographs was supposed to satisfy the requirements of realism, while at the same time ensuring-according to the mythology of the photographic medium - that they would continue to be the closest and most "objective" contact with reality. However, the way in which photographic material is juxtaposed remains a matter of artistic construction.

The interwar period covered a broad range of artistic practices in Poland leading up to the political climate of the Second World War. Beginning with the catalog of the Exhibition of New Art in Vilnius in 1923, Żarnower published numerous statements pertaining to her convictions about art and design and sought to put these notions into practice: "Changing the field of vision, technology has changed the means of expression by introducing new material and it has broadened the scope of unexpressed possibilities" (Żarnowerówna 1923). This text illustrates the ways in which early information about the Second World War created the context and motivation for Żarnower to expand her sphere of social influence. To this day, her practices present a rich source of experience that is notable and of great use in addressing a number of relevant questions.

\section{Materials and Methods}

Photomontage led me to photography.

Aleksander Rodchenko, Reconstruction of an Artist, 1935

Photography has broken free from being secondary and imitating the techniques of etching, painting or carpet making. Having found its own way it is blossoming and fresh breezes bring a scent that is particular only to photography. New possibilities lie ahead. The multitude of its aspects are as complex as fine drawing, more interesting than photomontage. (... ) Then follows the creation of non-existent photographic moments by means of montage. A negative instead of a positive creates a completely new perception. To say nothing of the printing of one picture into another (what is called an "influx" in the cinema), optical distortions, photograms, shots of reflections and so on.

Text written by Alexander Rodchenko on October 31, 1934 for the magazine Sovietskoye foto. First published in 1971.

During her exile which began in 1937 and became ever more stringent from 1939 onwards, Żarnower started her collection of photographic images. In her diary entry on 16 January 1941, Żarnower wrote:

Called upon by the Department of Propaganda of the Polish Government in Exile [Committee of the Council of Ministers for Information, Documentation, and Propaganda], I completed a number of propaganda posters that were also to appear in America as posters and picture postcards. I have recorded the War in Poland and the tragedy of the Polish nation caused by the occupants' violence in a number of photo-montages. I have also illustrated a book on ruined Warsaw that would have been published were it not for the downfall of France. 
Due to the German occupation beginning on 22 June 1940, Żarnower fled from France, traversing Spain and into Portugal via the cities of Angers and Lourdes with Franciszka Themerson, which she later recounts in a letter to a friend: "I have tender memories of our spirit stove, our stay in Angers and your sad eyes which went on to haunt me in Lisbon ... ". ${ }^{5}$ In 1941, she left Lisbon for New York however, upon arrival was denied permission to enter the country, due to the stringent American immigration policies of the time (Affron and Barron 1997, p. 225). Żarnower was forced to stay in Montreal for seventeen months while she negotiated her entry to the United States, which was finally achieved on 11 June 1943 where she settled in New York City. This period was a time of exile, as described by Edward Said:

... exile, unlike nationalism, is fundamentally a discontinuous state of being. Exiles are cut off from their roots, their land, their past. They generally do not have armies or states, although they are often in search of them. Exiles feel, therefore, an urgent need to reconstitute their broken lives, usually by choosing to see themselves as part of the triumphant ideology or a restored people. (Said 2000, p. 177)

Said's take on this is slightly complicated by Żarnower's use of her Warsaw photomontages. Indeed, her view on her connection for her land and past is visualized not in the idea of a glorious restoration, but in the concept of destruction, which has proven a powerful way to rouse political action. Without her army, or her state, stuck in the center of an "emotional geography", or what Andries Botha would refer to as the violation of a space that once was home, she took the stance of depicting broken lives with no restoration in sight.

In Photographing the Holocaust: Interpretations of the Evidence (2004), Janina Struk points out the reluctance of British and American governments to publish photographs of atrocities during the war, arguing that such evidence was Soviet or Jewish propaganda. The author mentions the endeavors of the exiled Polish Ministry of Information to publish a book in 1942 entitled The German New Order in Poland including 600 pages of photographs and documents chronicling the brutality of the German occupation (Struk 2004, pp. 5-6). Żarnower was acutely aware of the passing of time and her feelings of devastation about the war were only amplified by her access to photographs depicting military power, destruction, tragedy and death. The Defense of Warsaw was released just after the United States joined the Second World War by declaring war on Japan on December 8, 1941 and served as an urgent reminder that Poland was suffering at the hands of the Nazi occupation for over two years already. In Remembering to Forget: Holocaust Memory Through the Camera's Eye, Barbie Zelizer correlates the photographs taken at the liberation of the concentration camps in Germany after World War II to notions of collective memory and contemporary perception as they relate to the past atrocities. The emergence of the use of photography as journalistic reporting helped to shape this collective memory (Zelizer 2000). Żarnower's photomontages played a pivotal part in the formation of this canon of WWII imagery through the artist's prompt reaction to the events, via her role as critical commentator, and the montaging of the available war photographs into a book publication form.

Susan Sontag developed the idea between the poles of recoding the traumatic and presenting it to the public. Favoring the medium of photography over film, she wrote in her famous text On Photography:

Cameras began duplicating the world at that moment when the human landscape started to undergo a vertiginous rate of change: while an untold number of forms of biologic and social life are being destroyed in a brief span of time, a device is available to record what is disappearing. (...) A photograph that brings news of some unsuspected zone of misery cannot make a dent in public opinion unless there is an appropriate context of feeling and

5 Teresa Żarnower in: Teresa Żarnower (1897-1949). An Artist of the End of Utopia, eds. Ślizińska, Milada and Andrzej Turowski, Muzeum Sztuki in Łódź, 2014, p. 167. 
attitude. ( ... ) Photographs cannot create a moral position, but they can reinforce one-and can help build a nascent one. (... ) Photographs may be more memorable than moving images, because they are a neat slice of time, not a flow. (Sontag 2008, pp. 15-17)

In the very last chapter of her book Regarding the Pain of Others, Sontag refers to the snapshot of a little boy in the Warsaw Ghetto in 1943 which was used as a memento mori symbol and seen as a secular icon; raising the question of the appropriate place for displaying such photographs, which she describes as emblems of suffering. She perceives a difference in the reception of photographs depicting concentration camps, when shown in art galleries versus "printed on rough newsprint". She points out that museums provide distractions for such "solemn or heartrending subject matter" with regards to its reception and argues that due to "the weight and seriousness of such photographs [they] survive better in a book, where one can look privately, linger over the pictures, without talking" (Sontag 2003, pp. 119-21).

What was Żarnower's goal when she chose to illustrate a political text about atrocities in her home city based on documentary photography? What did it mean for her to work on them? What creative choices and artistic decisions was she faced with in constructing a model of historical memory? In Foreword: Non-memory (2014), Maria Poprzęcka provides valuable insights on the subject of the "conscious restitution of somebody else's memory" (Poprzecka 2014), concurring with Robert Traba's radical statement that "from a biologic point of view, collective memory does not exist" (Traba 2013, p. 23). Eviatar Zerubavel identifies the structure of collective memory as a socio-mental typography, contrasting it with the psychology of memory, yet continuing to refer to mnemonic communities and traditions over the individual experience of memory (Zerubavel 1997, pp. 17-18, 87-91, 95-96; 2004). How private, personal and collective was Żarnower's response to "fracturing events in history"? What type of response was Żarnower expecting when creating the photomontages? At the beginning of Siegfried Kracauer's Die Photographie [Photography] essay, he states:

What the photographs by their sheer accumulation attempt to banish is the recollection of death, which is part and parcel of every memory image. In the illustrated magazines the world has become a photographable present and the photographed present entirely eternalized. Seemingly ripped from the clutch of death, in reality it has succumbed [to] it.

(Kracauer 1927)

In this same pattern of thought, the question arises around whether Żarnower succumbed to death while focusing and delving into photographs of it. Working from Paris, her escape city-and later from Canada - the country that rescued her from physical trauma, Żarnower's montage was utilized as a mediating device. In her immediate reaction to the materials she possessed, she systematically organized knowledge as mnemonic devices spurring political action. The same methodology is followed in another of Żarnower's works, namely in Photomontage for Canadian Troops published in 1942 (Figure 10). Such esthetic solutions introduce an alternative view of war and memory, rupture in perception, shocking moments and the works provide the viewer with a strong and instantaneous presence. As Warburg would imply, an "attempt to construct collective historical memory would focus on the inextricable link between the mnemonic and the traumatic" (Buchloh 1999, pp. 119-22). Zarnower's integral strategy when thinking about the collective reception was to utilize the fragmentary nature of memory of place as a way to draw on people's emotions while simultaneously exposing the viewer to a specific type of shocking imagery. 


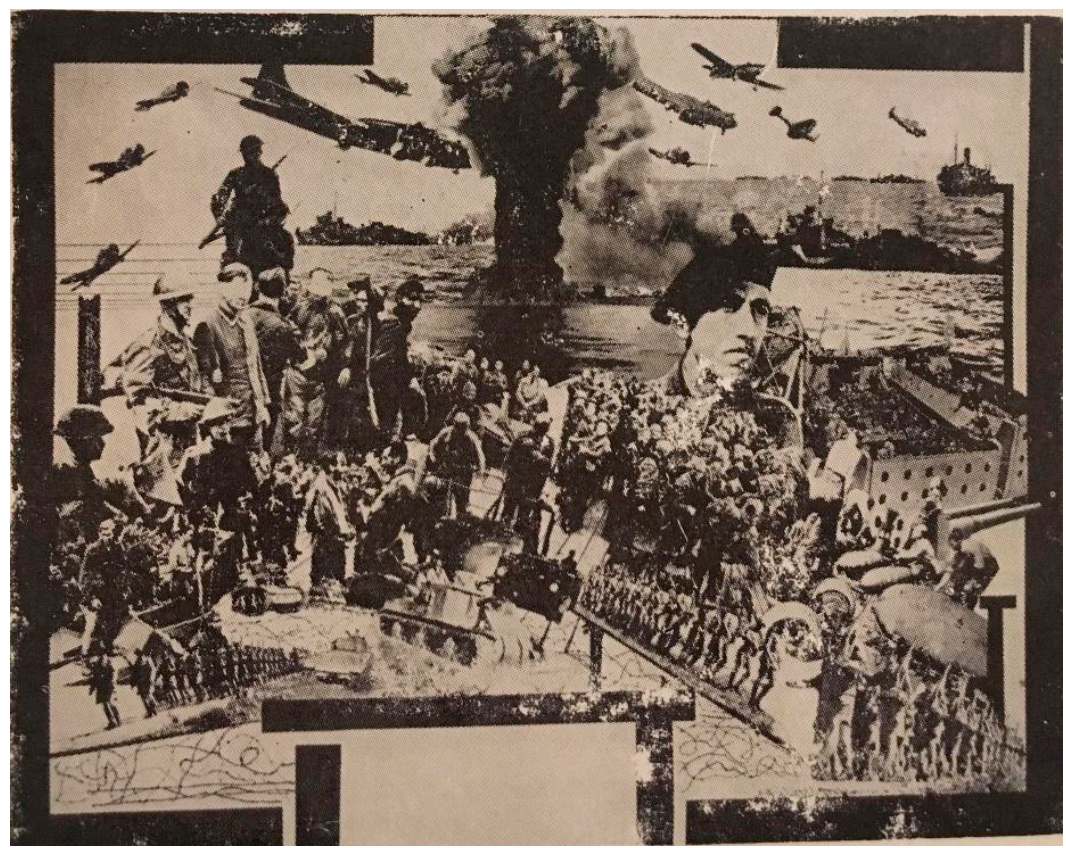

Figure 10. Teresa Żarnower, Photomontage for Canadian troops, 1942, The New York Public Library, public domain image.

\section{Conclusions}

To conclude, the studies above clearly embodied the politics of mobility: through the shift in methodology from the analysis of artistic creativity in an artist's own country of origin to their spatiotemporal transfer to the Western canon of the 1940s in the United States. The focus was on the relation of art and social life framed by memory, as well as addressing a change in reception of war photomontages. This shift appeared independently: Żarnower's photomontages were neither subject to the Polish government's propagandistic influences, nor (well, certainly not yet) to the cultural industry of Western capitalism. Interpreting Zaremba's testimony on the invasion of Warsaw by Hitler's army in September 1939 through critically photomontaging the events that occurred in her home city, as well as relying on the visual evidence of documentary photography rather than propagandist textual accounts, enabled the artist's individual voice to be revealed. Additionally, this engendered and brought to the public eye, the comparative pairing of both approaches of communicating history. Just as Lucia Moholy-Nagy struggled to retrieve her negatives from Walter Gropius when she was exiled after fleeing from Nazi Germany in the 1930s, the possession of photographic materials was, for Żarnower too, of the highest priority. This, in order for the work to be propagated to the broadest audience in a time when common war imagery was highly censored. Żarnower, who was trained according as a productivist, utilitarian artist focusing on the proletarian society of the interwar period, was able to present, overcoming the struggles of exile, shocking new war photography to a capitalist, industrial Western society.

Żarnower's photomontages were born out of the audacious combination of a variety of genres, dynamic composition and a documentary approach. In The Defense of Warsaw, the editor contrasted the photos and photomontages of war in the book making use of symmetrical layouts, careful shape choices producing a sense of equilibrium and in a serially organized configuration. By combining images, Żarnower created a new sense of space, which mirrored her comprehensive narrative style. This new style itself was characterized by its productivist esthetics, which maintained features of both a constructivist approach with the use of abstract motifs and of social realism in the way it bonded large amounts of visual information. She managed to mediate the indexical sign incorporated in photography, which was apparent through the cropping, reduction and flattening of the photomontages in The Defense of Warsaw and thus, prevailed as both abstraction and reality (Krauss, pp. 58-60). 
Therefore, Żarnower succeeded in building a model of social memory based on the fragmentary methods of extracting and serializing shocking imagery. The recurring image of war became her new scene, altering the scope of her vision and allowing her to move from the constructor of the new utopian world to the deconstructor of the realistically ruined one.

Funding: This research received no external funding.

Acknowledgments: I would like to thank for the critique of my paper on Żarnower received during the workshop Exiled Artists and Intellectuals during the 20th century organised by METROMOD at the German Center for Art History in Paris, which took place on 3-4 July 2019.

Conflicts of Interest: The author declares no conflicts of interest.

\section{References}

Affron, Matthew, and Stephanie Barron. 1997. Exiles + Emigrés: The Flight of European Artists from Hitler. New York: Los Angeles County Museum of Art.

Allen, Stan. 2009. Practice: Architecture, Technique + Representation. London: Routledge.

Anagnost, Adrian. 2016. Teresa Żarnower: Bodies and Buildings. Woman's Art Journal 37: 38-49.

Badger, Gerry. 2014. The Genius of Photography: How Photography Has Changed Our Lives. London: Quadrille.

Baranowicz, Zofia. 1975. Polska Awangarda Artystyczna 1918-1939. Warszawa: Wydawnictwa Artystyczne i Filmowe.

Berman, Mieczysław. 1965. Teresa Żarnowerówna kontynuatorem dzieła Mieczysława Szczuki [Teresa Żarnowerówna as a continuator of Mieczysław Szczuka's work]. In Mieczystaw Szczuka. Edited by Anatol Stern and Mieczysław Berman. Warszawa: Wydawnictwa Artystyczne i Filmowe.

Bois, Yve-Alain. 1990. Painting as Model. Cambridge: MIT Press.

Buchloh, Benjamin. 1984. From Faktura to Factography. October 30: 82-119. [CrossRef]

Buchloh, Benjamin. 1999. Gerhard Richter's Atlas: The Anomic Archive. October 88: 117-45. [CrossRef]

Czekalski, Stanisław. 2000. Avant-Garde and the Myth of Rationalization: Polish Photomontage 1918-1939. Poznań: Wydawnictwo Poznańskiego Towarzystwa Przyjaciół Nauk.

Giżycki, Marcin. 1996. Awangarda Wobec Kina: Film w Kregu Polskiej Awangardy Artystycznej Dwudziestolecia Międzywojennego. Warsaw: Wydawnictwo Małe.

Grabska, Elżbieta. 1982. The Years 1914-1918 and 1939-1949. The Problems of Periodisation of the Inter-War Period. In Art in the Inter-War Period. Warsaw: PWN.

Gurianova, Nina. 2012. The Aesthetics of Anarchy. Art and Ideology in the Early Russian Avant-Garde. Berkeley: University of California Press.

Jaworowska, Janina. 1976. Polska Sztuka Walczaca 1939-1945 [Polish Fighting Art 1939-1945]. Warsaw: Wydawnictwa Artystyczne i Filmowe.

Józefacka, Anna. 2011. Rebuilding Warsaw: Conflicting Visions of a Capital City, 1916-1956. Ph.D. dissertation, New York University, New York, NY, USA.

Kracauer, Siegfried. 1927. "Die Photographie" Frankfurter Zeitung. Reprinted in Siegfried Kracauer, The Mass Ornament. Edited and Translated by Thomas Levin. Cambridge: Harvard University Press.

Król, Monika. 2002. Collaboration and Compromise: Women Artists in Polish-German Avant-Garde Circles, 1910-1930. In Central European Avant-Gardes: Exchange and Transformation, 1910-1930. Edited by Timothy O. Benson. Cambridge: MIT Press.

Lewandowska, Bożena. 1966. U Źródeł Grafiki Funkcjonalnej w Polsce. In Ze Studiów nad Geneza Plastyki Nowoczesnej w Polsce. Edited by J. Starzyński. Wrocław: Ossolineum.

Malinowski, Jerzy. 1987. Grupa Jung Idysz i żYdowskie Środowisko Nowej Sztuki w Polsce, 1918-1923 (The Young Yiddish Group and the Jewish Context for New Art in Poland, 1918-1923). Warsaw: Polska Akademia Nauk, Instytut Sztuki.

Mansbach, S. A. 1999. Modern Art in Eastern Europe: From the Baltic to the Balkans, ca. 1890-1939. Cambridge: Cambridge University Press.

Margolin, Victor. 1997. The Struggle for Utopia: Rodchenko, Lissitzky, Moholy-Nagy 1917-1946. Chicago and London: The University of Chicago Press.

Mertins, Detlef. 2001. Architectures of Becoming: Mies van der Rohe and the Avan-Garde. In Mies in Berlin. Edited by Terence Riley and Barry Bergdoll. New York: Muzeum of Modern Art, pp. 106-33. 
Morawińska, Agnieszka. 1991. Artystki Polskie: Katalog Wystawy. Warsaw: National Museum in Warsaw.

Piotrowski, Tadeusz. 1998. Poland's Holocaust: Ethnic Strife, Collaboration with Occupying Forces and Genocide in the Second Republic, 1918-1947. Jefferson: McFarland.

Poprzęcka, Maria. 2014. Foreword: Non-Memory. RIHA Journal 2014 (Special Issue Contemporary Art and Memory): 0104. Rypson, Piotr. 2011. Against All Odds. Polish Graphic Design 1919-1949. Krakau: Karakter.

Said, Edward. 2000. Reflections on Exile and Other Literary and Cultural Essays. London: Harvard University Press. Ślizińska, Milada, and Andrzej Turowski. 2014. Teresa Żarnower (1897-1949). An Artist of the End of Utopia. Łódź: Muzeum Sztuki in Łódź.

Sontag, Susan. 2003. Regarding the Pain of Others. New York: Macmillan.

Sontag, Susan. 2008. On Photography. London: Penguin Modern Classics.

Stierli, Martino. 2018. Montage and the Metropolis. Architecture, Modernity, and the Representation of Space. New Haven and London: Yale University Press.

Struk, Janina. 2004. Photographing the Holocaust: Interpretations of the Evidence. London: I.B. Tauris.

Suzuki, Sarah. 2004. Deborah Wye. In Artists and Prints: Masterworks from The Museum of Modern Art. New York: The Museum of Modern Art.

Traba, Robert. 2013. Traba, Robert. Konieczność zapominania, czyli jak sobie radzić z ars oblivionis [The need to forget, that is how to deal with ars oblivionis. Herito 13: 22-29.

Turowski, Andrzej. 1981. Konstruktywizm Polski. Próba Rekonstrukcji Nurtu (1921-1934). Wrocław: Polska Akademia Nauk, Instytut Sztuki.

Turowski, Andrzej. 2000. Budowniczowie Świata: z Dziejów Radykalnego Modernizmu w Sztuce Polskiej [Builders of the World. The History of Radical Modernism in Polish Art]. Kraków: Universitas.

Vattano, Starlight. 2018. Graphics Analysis of the Projekt Kina by Teresa Żarnowrówna, 1926. In Women's Creativity since the Modern Movement (1918-2018). Toward a New Perception and Reception. Edited by Helena Seražin, Emilia Maria Garda and Caterina Franchini. Ljubljana: France Stele Institute of Art History.

Witkovsky, Matthew, and Peter Demetz. 2007. Foto: Modernity in Central Europe, 1918-1945. Washington: National Gallery of Art in association with Thames and Hudson.

Żarnowerówna, Teresa. 1923. Constructivism in Poland 1923-1936. Catalogue of the Exhibition of New Art. Cambridge: Kettle's Yard Gallery, pp. 25-27.

Zelizer, Barbie. 2000. Remembering to Forget: Holocaust Memory Through the Camera's Eye. Chicago: University of Chicago Press.

Zerubavel, Eviatar. 1997. Social Mindscapes: An Invitation to Cognitive Sociology. Cambridge: Havard University Press. Zerubavel, Eviatar. 2004. The social marking of the past: Toward a socio-semiotics of memory. In Matters of Culture. Cultural Sociology in Practice. Edited by Roger Friedland and John Mohr. Cambridge: Cambridge University Press, pp. 184-95.

Zimmerman, Joshua D. 2003. Contested Memories: Poles and Jews During the Holocaust and Its Aftermath. New Brunswick: Rutgers University Press.

(C) 2020 by the author. Licensee MDPI, Basel, Switzerland. This article is an open access article distributed under the terms and conditions of the Creative Commons Attribution (CC BY) license (http://creativecommons.org/licenses/by/4.0/). 